\title{
PRINCIPAL NEW ZEALAND EARTHQUAKES IN 1981
}

\author{
Warwick D. Smith*
}

During the year there were three earthquakes greater than magnitude 6 within the New Zealand region. This is an unusually large number, but none caused any damage. The April 4 event, of magnitude 6.0, was deep under Lake Taupo and the magnitude 6.3 shock on November 17 was to the northwest of White Island, some $200 \mathrm{~km}$ deep. Both of these were felt widely, but were of such a depth as to present no danger. The largest event of the year was shallow (about $15 \mathrm{~km}$ deep), and thus potentially damaging, but was located $400 \mathrm{~km}$ southwest of Stewart Island. It occurred on May 25 and was of magnitude 6.4. It was felt in Southland and Otago and as far north as Christchurch, but nowhere very strongly. A small tsunami, $30 \mathrm{~cm}$ in height, was observed at Campbell Island on this occasion.

Two moderate earthquakes shook the Wairarapa late in the year. Both were centred near Cape Turnagain. The first was of magnitude 5.3 and occurred on November 5. The second, of magnitude 5.5, occurred on December 28. The felt areas extended to Wellington and Hawke's Bay and on the north east, to Taihape on the first occasion and to ohakune on the second. No damage was reported.

There were a number of small shocks throughout the year, sufficient to wake sleepers and to cause some alarm, but there was no significant damage. An unusually high proportion of these were felt in Hawke's Bay, but there is no suggestion that this necessarily portends any large event imminent there. On January 6 at $6.35 \mathrm{am}$. there was a small shock felt in Napier, and again on Saturday morning, February 14. Two slightly larger shocks, both of magnitude 5 , occurred on April 21 and 22, both felt in Napier. Early in December a further series of small earthquakes were felt in Napier and Hastings, the largest reaching magnitude 4. On June 15 a small shock of magnitude 4.6 was felt in Westport, Murchison and Greymouth. No damage was reported.

\section{TECHNICAL NOTE:}

COMPUTER ANALYSES OF NEW ZEALAND EARTHQUAKE ACCELEROGRAMS - VOLUME I

by J.L. Beck**,P.M. Randal**and R.T. Hefford**

The Engineering Seismology section of the Physics and Engineering Laboratory, DSIR, has recently published the above volume presenting the results of computer analyses of twenty, three-component, accelerograms recorded by the New Zealand Strong-Motion Network. It contains a brief introduction, three tables summarising the accelerogram characteristics, site information and earthquake information, and the results of the computer analyses. The results presented for each accelerogram

* Seismological Observatory, DSIR, Wellington.

**Physics and Engineering Laboratory, DSIR,

Lower Hutt.

BULLETIN OF THE NEW ZEALAND NATIONAL SOCIETY FOR EARTHQUAKE ENGINEERING, VOL. 15, NO. 1, MARCH 1982 begin with a heading page, followed by. computer plots of acceleration, velocity and displacement histories, acceleration response spectra and Fourier amplitude spectra. The spectral values are also tabulated.

The table below summarises details of the acceleration amplitudes, sites and earthquakes of the twenty accelerograms included in the volume. The range of peak horizontal accelerations is from 3 to $19 \% \mathrm{~g}$, including the strongest shaking measured since the inception of. the network in 1965. Both ground and structural sites are included.

Copies of the volume are being supplied to the Engineering School libraries at Canterbury and Auckland, to the MWD library in Wellington, and to other organisations with which an arrangement for exchange of information exists. Copies may also be purchased from PEL for $\$ 20$.

Magnetic tape of 8" IBM floppy diskette copies of the computer files from which the report was compiled are also available for $\$ 20$. Purchasers must supply their own clean tapes or diskettes. The preferred tapes are 9-track $1600 \mathrm{bpi}$, but 7-track 800 bpi can also be handled. The request for tape copies should also include a contact name, and indicate any special tape specifications required (e.g. to allow use of existing programs written for Caltech tapes). Floppy diskettes can be written in either single-density (10 diskettes required) or doubledensity ( 5 diskettes required). The files contain the accelerogram heading information, the accelerations, velocities and displacements plotted but not listed in the report, and the tabulated spectral values.

Enquiries should be addressed to -

Engineering Seismology Section, Physics and Engineering Laboratory, DSIR, Private Bag, Lower Hutt. 